\title{
The Guerrilla Literacy Learners Project: Development of Literacies through Informal Learning
}

\author{
Alena Jůvová* \\ Received: September 30, 2016; received in revised form: March 21, 2017; \\ accepted: March 23, 2017
}

\begin{abstract}
:
Introduction: This paper deals with the options of non-formal education and, partially, a set of literacies developed within informal learning, which an individual should be equipped with in order to succeed in life in the contemporary society. At the beginning, there is a mention to the nature of learning and knowledge of society in the context of lifelong learning.

Purpose: The aim of the paper is to analyse and explain non-formal education in contemporary society of knowledge and, subsequently, to provide examples of its use when developing operational literacy. This literacy can be defined as an individual's ability to be nimble, proactive, and responsive to various life situations.

Methods: The paper serves as an overview study of the subject. For a literary analysis, the methods of comparison and content analysis were used with examples of good practice at the end.

Conclusions: At the end of the paper, one can find an example of the international project "Guerrilla Literacy Learners" the goal of which is to find innovative strategies for informal learning and to develop a methodology that would support the development of literacy and active knowledge of a foreign language by using modern teaching resources, such as ICT, visually attractive materials and adequate methods - MOOC and blended learning.
\end{abstract}

Key words: knowledge and learning society, literacy, non-formal and informal learning, lifelong learning.

\footnotetext{
* Alena Jůvová, Institute of Education and Social Studies, Faculty of Education, Palacký University in Olomouc, Olomouc, Czech Republic; alena.juvova@upol.cz
} 


\section{Acta Technologica Dubnicae \\ volume 7,2017 , issue 1}

\section{Introduction}

At the beginning, there is a need to mention the concept of the knowledge society and the differences between education and information society as presented by individual authors. Later, the text deals with the position of informal learning among the contemporary educational strategies. The concept of knowledge society is based on Bell's theory of post-industrial society, which, in its development, distinguishes between the pre-industrial, industrial and postindustrial phases. For the post-industrial phase, the services sector and information sharing are crucial (Bell 1973; Dopita, 2010). Not theoretical but applied knowledge dominates here (Šima, 2006). In the post-industrial society, the main issue is the organization of science, with university being a leading institution. Science becomes an independent and distinct activity. As reported by Reich (1992), in this type of society, which is booming and the use of ICT is present there, information replaces physical capital and thus becomes a key strategic resource. Information literacy is becoming an essential part of education and the level of its mastery then affects the state of social structure to a certain extent. The economy is based on the distribution and use of information - knowledge; we talk about the so-called super-symbolic economy (see Toffler and Toffler, 1996; Kolomazník, 2000). Information is a specific product of culture, tradition, economic and educational policy of each country.

\section{Knowledge and Learning Society}

The European civilization is based on the concept of science as an independent and distinct activity (Cílek, 2008). Knowledge society is a concept that the European education system is trying to reach. Knowledge in national education systems is produced, distributed and applied in a specific way, which tracks the culture, traditions, education policy and economic status of the country (Petrusek, 2007). The notion of knowledge society that was firstly used by Peter Drucker (The Landmarks of Tomorrow, 1959), is gradually emerging in political documents of international and state organizations. The creation of knowledge society has become a political objective of developed countries (Šima, 2006; Veselý, 2004). Knowledge society is understood both as a society, where the aim is to achieve education and the type of society in which "knowledge becomes the dominant productive force" (Veselý, 2005). The concept of lifelong learning should contribute to achieving this stated objective. The idea of lifelong learning is enshrined in the basic documents of the European Union, which form a general framework for setting educational policy strategies of the member states (White Paper on Education and Training, 1995; Delors, 1996).

The framework of the curriculum should be based on general competencies and specific multidisciplinary, interdisciplinary and disciplinary competencies: 


\section{Acta Technologica Dubnicae \\ volume 7, 2017, issue 1}

- Learning to learn and to think;

- Learning to communicate;

- Learning to live together;

- Learning to be oneself;

- Learning to do it and initiate/undertake (Tawil \& Cougoureux, 2013).

The concept of lifelong education/learning in the context of the priorities of the educational policy of the European Union does not apply only to the individual activities of individuals, but extends its effect to the whole society in which individuals are motivated to lifelong learning. The aim is to create a learning society, in which every individual should have the ability/competence and motivation to learn throughout their whole life. Lifelong learning, apart from adult education, also includes children and youth in schools and extracurricular education, formal and non-formal education outside the school. According to the EU, lifelong learning is a tool for social inclusion, it should serve to reduce social inequalities in the society, reduce unemployment and increase competitiveness in the labour market. In a broader perspective, a higher level of education in society should bring the development of democracy and civil society in terms of active citizenship and community development/life. Therefore, it is obvious that the individual and his/her needs must become the centre of attention in education (European Commission Memorandum of 30 October, 2000 on Lifelong Learning). The system of all forms of education should be as open as possible and should be based on the use of all the available methods and means leading to successful in the learning process. "Lifelong learning should be the key to social integration and equality" (European Commission Memorandum of 30 October, 2000 on Lifelong Learning).

In the Czech Republic, there are efforts to achieve the status which can be seen in some political activities, as well as in activities in schools and in those performed by teachers, academicians and professionals.

Currently, we promote the concept of inclusion of pupils with special educational needs in regular schools, but these efforts do not meet with a positive reaction mainly on the side of teachers and schools that typically do not have sufficient funds and adequate staffing as for special education teachers or teaching assistants.

Experts from Palacký University in Olomouc prepared a collaboration with the non-profit organization "Člověk v tísni" (People in Need), a program of inclusion for the Czech Republic, being implemented to Czech schools since the academic year 2016/2017. 


\section{Acta Technologica Dubnicae \\ volume 7,2017 , issue 1}

It is a two-year project called "Systemic support for inclusive education in the Czech Republic". From the perspective of the research team (almost 600 writers, teachers, guidance counsellors, directors, officers, regional and municipal authorities and others), the past period has brought many interesting experiences (see http://www.inkluze.upol.cz/portal/ and https://www.clovekvtisni.cz/en).

In the field of non-formal education, in the Czech Republic, there is an emphasis on the wide range of extra-curricular activities for pupils of younger and older school age and adults, for example, in sports Sokol (Falcon), Orel (Eagle), etc.; arts; culture; or leisure activities in natural sciences and technology. Also, there are traditional tourist clubs, such as Skaut (Boy Scout) and Pionýr (Pioneer). Basic art schools with the fields of music, dance, art and drama and language schools have a long tradition in the Czech Republic. Since 1989, associations and private subjects alongside state institutions play a role in non-formal education.

The concept of lifelong learning reflects both the theories of adult education and biodromal or social education, and, practically, the implementation of adult lifelong learning, retraining courses financed by government, corporate or private agencies. In the field of education, we talk about training teachers to enhance or supplement their qualifications.

A learning society and lifelong learning have been the most important aims since 1996, when the document called "Learning: The Treasure Within" was published: "With the lifelong learning paradigm set as a backdrop, the report is based on four key pillars underlying education and life: learning to know, learning to learn, learning to do, learning to be, and learning to live together" (Delors, 1996). Another significant illustration of the influence of the four pillars of learning on curriculum development is in the area of Education for Sustainable Development (ESD). Indeed, the four pillars outlined in Delor's report have been used in the ongoing work - coordinated by the United Nations Economic Commission for Europe - to define ESD competencies required by educators (Tawil \& Cougoureux, 2013). The aims for lifelong learning were formulated in the Köln Charter: Aims and Ambitions for Lifelong Learning (1999).

Changes in the current educational reality have been summarized by Orr, Rimini and Van Damme (2015) into six key educational challenges:

- Fostering the use of new forms of learning for the 21 st century.

- Fostering teachers' professional development and engagement.

- Containing public and private costs of education.

- Continually improving the quality of educational resources.

- Widening the distribution of high-quality educational resources. 


\section{Acta Technologica Dubnicae \\ volume 7, 2017, issue 1}

- Reducing barriers to learning opportunities.

In reflection of these changes, teachers and pupils have new opportunities for the use of non-traditional and modern, new forms of learning methods and strategies for effective learning.

Also, open educational resources should help this purpose. "OER offer the possibility of reducing these costs through developing, sharing and updating resources costs more effectively. The dynamics of knowledge society leads to three challenges for educational resources: they must reflect new developments in the subject area they cover, they must reflect new learning theories in order to better support high-quality learning, and they must be fit for purpose for the expected learning outcomes and the heterogeneous group of learners who are using them" (Orr, Rimini, \& Van Damme, 2015).

The paradigm of the relationship between teachers and pupils changes here. In the contemporary constructivist approach to learning, the aim is a self-directed learning, in which teachers help pupils by mentoring, tutoring or coaching. The intensity and extent of teachers' assistance depends on the pupils' age - first you need to show the way to learning to the children, to support their curiosity, and then teach them to learn and benefit from modern means, such as ICT, visually attractive materials and adequate methods - MOOC, blended learning etc. (see Jůvová et al., 2015).

According to the theory of social constructivism, the teacher helps to create and construct educational reality by organizing the educational environment and external educational conditions. An individual acquires knowledge by subjective, personal life experience, in everyday situations and in social interactions of everyday life in the society.

The personality of a modern teacher plays an important role here. Such a modern teacher:

- has perfect theoretical preparation,

- is oriented towards the practical aspects of education,

- is progressive in education (Jůvová et al., 2015).

It is, therefore, a substantial change in the interaction between teachers and pupils towards (self)learning management, with an emphasis on high quality teaching communication between pupils and teachers, creating a positive educational climate, intense motivation for learning using ICT and all the opportunities provided by informal learning. 


\section{Acta Technologica Dubnicae \\ volume 7, 2017, issue 1}

\section{Literacy and informal learning}

Informal learning has an important role in the process of lifelong learning. We talk about informal education if it is a doctrine that is not institutionally anchored and unlike formal or non-formal education, it does not lead to obtaining a certificate of knowledge achieved. This type of learning can take place at any stage of life of an individual, at any place and in any environment. Depending on whether the individual is aware of the fact that he/she acquires new knowledge with a specific goal or intention or not, we distinguish between intentional and unintentional informal learning (see Rabušicová \& Rabušic; Straka, 2009).

It is a parallel process that takes place in all stages of formal and non-formal education simultaneously. At the school level, it is a part of the so-called hidden curriculum, in which education takes place outside the official framework. Any act of communication by the teacher or the dynamics of informal relationships associated with the exchange of information between all actors in the process of education (pupils, teachers, family and community), can be included here. The concept of informal learning is one of the key concepts of educational policy of the European Union and national policies of the member states, including the Czech Republic. "Informal learning is a natural accompaniment to everyday life. Unlike formal and non-formal learning, informal learning is not necessarily intentional learning, and so may well not be recognised even by individuals themselves as contributing to their knowledge and skills" (European Commission Memorandum of 30 October, 2000 on Lifelong Learning).

Although the documents of the European Union (European Commission Memorandum of 30 October, 2000 on Lifelong Learning) include informal learning, together with formal and non-formal education, among the three core areas of education policy, for an individual, it is not possible to determine its quality or to assess the extent and nature of thusly gained new knowledge or skills.

We need to ask some important questions, such as how the potential of informal learning can be used for the benefits of the society and individuals; and whether it is possible to achieve through not only the expansion of the cultural capital of individuals, but also by contributing to a better labour market. To achieve that, one must create a uniform definition of the concept of informal learning, to determine its quality indicators and determine the procedures for evaluation. We believe that due to the very nature of informal learning, it will be a complicated process with an unclear outcome. It should be emphasized that informal learning does not provide a comprehensive and systematic review of the evidence given in science disciplines or in other fields of human activities. Providing 


\section{Acta Technologica Dubnicae \\ volume 7, 2017, issue 1}

information may be random, chaotic and does not need to provide skills that are essential for a deeper understanding. In the reflection on current events, we come to the conclusion that informal learning may be the basis for social pathology of the individual. Nevertheless, we must pay a close attention to informal learning, as it offers a considerable potential for lifelong learning and is an important addition to formal and non-formal education, the results of which can be positively influenced.

\section{Guerrilla Literacy Learners Project and Operational Literacy}

“Our future depends upon people, skilled people."

Marianne Thyssen

Considering all the above-mentioned possibilities, there are new concepts emerging for the use of informal learning in normal school education. One of them is the Guerrilla Literacy Learners Project (GuLL), part of Erasmus+ KA2.

The international Guerrilla Literacy Learners Project (GuLL) concentrates on a student-centred approach which helps language learners improve their language acquisition skills. It focuses on identifying hidden policies, and on searching for new methods in the process of foreign language learning. Apart from qualitative and quantitative research probes made, there are important elements, such as storytelling, the methodology of work with errors and intervention in favour of motivation to learn foreign languages.

As clear from the Global Monitoring Report Education for All: Teaching and learning: Achieving quality for all (UNESCO, 2014), there is a current global crisis of education where 250 million out of 650 million primary school children are not taught basic literacy skills in Western Europe, however, $96 \%$ reach 5thgrade level reading skills. Nevertheless, Europe is confronted with a very large group of students who are unable to acquire basic literacy, while one student of 15 in the population aged 15 years old still cannot read properly (UNESCO, 2014). What is more, more than 70 million adults in Europe have poor reading, writing, numeracy and digital skills (Thyssen, 2016). In the Czech Republic, the percentage of literacy is around $99 \%$ - in the international PISA comparisons. PIAAC in the Czech Republic is above average values (Simonová, 2010; OECD, 2016).

Early school leaving is another problem, when many students stopped studying, although they could have become very good professionals in various fields. As a 


\section{Acta Technologica Dubnicae \\ volume 7, 2017, issue 1}

consequence, teachers and researchers are looking for new ways of teaching basic literacy skills.

Literacy used to be taught from functional to social and critical literacy with the presumption being that you need the operational literacy to be able to participate in the society. The modern society, however, sees citizens who are socially and critically literate without being operationally literate. "Literacy programmes usually allow individuals to acquire knowledge and skills through a variety of activities, promote informal learning, and encourage people to make and follow their own educational plans. In order to create the scope for literacy practice and for acquiring life skills, access to information and organisation of community development, and activities with local initiatives should become the major focus of literacy programmes" (Alam, 2004).

Operational literacy can be defined as an individual's ability to be nimble, proactive, and responsive to various life situations. All these changes provide challenges to literacy learning and, thus, call for a new didactical approach. "As well as supporting broader social development, people rightly expect that their education and training will help them to get a good job" (Thyssen, 2016).

"The common task for schools, families and the community is then to prepare children for life as successful active persons/citizens, thus, to develop and cultivate flexibility and resilience of children for being able to respond adequately to diverse life situations and social changes brought by the development of technology and science and the related differentiation of the society. The point is to find an identity and a satisfactory way of life that corresponds with the aim of achieving a high quality of life" (Jůvová \& Bakker, 2015).

GuLL switches from how learners should learn to how they actually learn, thus, embracing the European recommendation that if students fail to learn, teachers might want to teach in a different way. GuLL asked learners to reflect upon the unorthodox links (Guerrilla patterns) they make and then remediate it.

GuLL embraces an evidence-based approach linking learners' and teachers' experiences to academic research on literacy and, therefore, it offers a threepronged trajectory:

- It empowers learners by coaching them into autonomous learners.

- It improves the teaching practice by connecting it to non-formal and informal learning.

- It creates an inclusive language learners' space as GuLL organises these learning steps in MOOC and Facebook groups. 


\section{Acta Technologica Dubnicae \\ volume 7,2017 , issue 1}

The methodology and the concept of the project are based on the knowledge of social and educational constructivism, on a deliberate approach to pupils and the use of less traditional teaching methods. These include the method of graphic facilitation/custom design, motivating students to create short video clips and their activation through narration or creative writing.

The outputs of the project include a project website (www.pleasemakemistekes.eu) and knowledge-clips in which the basic problems teachers may face in education are referred to through the narration. Besides school education, these products can also be applied in schools or public libraries. Library staff can find new and interesting ideas to support effective formal and non-formal language learning for different age groups, either through workshops or through online activities.

\section{Conclusions}

Through the activities and outputs of the GuLL project, each individual has an access to non-conformist ways of new knowledge and literacy acquisition not only in learning but also in gaining the necessary confidence in communication in a foreign language.

This article is dedicated to Project Erasmus+ KA2 2014-1-BE02-KA200-000472 Guerrilla literacy learners (GuLL).

\section{References}

Alam, K. R. (2004). Operational definition of literacy for assessment purposes: Literacy to meet basic learning meeds. Adult Education and Development, 61, 41-50. Retrieved from: https://www.dvv-international.de/ adult-education-and-development/editions/aed-612003/

Delors, J. (1996). Learning: The treasure within. Report to UNESCO of the International Commission on education for the twenty-first century. Paris: UNESCO. Retrieved from: http://www.unesco.org/education/pdf/ 15_62.pdf.

Drucker, P. (1959). Landmarks of tomorrow: A report on the new "post-modern" world. Transaction Publisher.

EUR-Lex (2000). Commission memorandum of 30 October, 2000 on lifelong learning. Retrieved from: http://eur-lex.europa.eu/legal-content/CS/TXT/ ?uri=uriserv\%3Ac11047

EUR-Lex (2013). Opening up education: Innovative teaching and learning for all through new technologies and open educational resources. Retrieved from: http://eur-lex.europa.eu/legal-content/EN/TXT/?qid=1389115469384 \&uri=CELEX:52013DC0654 
European Commission. (1995). White Paper on teaching and learning: Towards the learning society. Retrieved from: http://europa.eu/documents/comm/ white_papers/pdf/com95_590_en.pdf

Jůvová, A., \& F. Bakker. (2015). Didactic principles by Comenius and 21st century skills. e-PEDAGOGIUM, 2, 7-20.

Jůvová, A. et al. (2015). Reflection of constructivist theories in current educational practice. Universal Journal of Educational Research, 3(5), 345-349. Retrievd from: http://www.hrpub.org. DOI: 10.13189/ ujer.2015.030506

Kolomazník, J. (2000). K některým sociálním aspektům a posunům v koncepcích postindustriální a informační společnosti. Sociologický časopis, 36(2|, 221-232. Retrieved from: http://sreview.soc.cas.cz/uploads/ fd9e85ba3e16ada6a052eb0d20dc73d60fb3647a_386_221KOLOM.pdf

Köln Charter: Aims and ambitions for lifelong learning (1999). Retrieved from: http://www.mofa.go.jp/policy/economy/summit/1999/charter.html

Liessmann, K. P. (2006). Theorie der Unbildung: Die Irrtümer der Wissensgesellschaft. Wien: Zsolnay.

Modern teacher. A revolutionary platform for teaching and learning in the digital world. Retrieved from: https://modernteacher.com/\#products.

OECD. (2016). Skills matter: Further results from the survey of adult skills, Paris: OECD Publishing. Retrieved from: http://www.oecdilibrary.org/education/skills-matter_9789264258051-en DOI: http://dx.doi. org/10.1787/9789264258051-en

Orr, D., Rimini, M., \& Van Damme, D. (2015). Open educational resources: A catalyst for innovation, educational research and innovation. Paris: OECD Publishing, Retrieved from: http://dx.doi.org/10.1787/9789264247543-en.

Oosterlinck, A. (2014). "Leraren hebben een te Laag niveau". Knack. Retrieved from: http://www.knack.be/nieuws/belgie/leraren-hebben-een-te-laagniveau/article-normal-137015.html

Rabušicová, M., \& Rabušic, L. O informálním učení v České republice. Retrieved from: http://www.phil.muni.cz/wupv/home/Documents/mpsvprojekt-prezentace/O\%20informalnim\%20uceni\%20v\%20Ceske\%20republ ice.pdf

Reich, R. (1992). The Work of Nations. New York: Random House.

Simonová, N. (2010). „Výzkumy funkční gramotnosti dospělých - SIALS a PIAAC." Socioweb, $4 . \quad$ Retrieved from: http://www.socioweb.cz/upl/ editorial/download/178_soc.web.4\%202010.pdf.

Straka, G. A. (2009). Informal and implicit learning: concepts, communalities and ifferences [Informální a implicitní učení: pojetí, komunality a rozdíly]. EJVT, 48, 132-145. Retrieved from: http://www.cedefop.europa.eu/ EN/Files/EJVT48_en.pdf). 


\section{Acta Technologica Dubnicae \\ volume 7,2017 , issue 1}

Šima, K. (2006). Paradigma společnosti vědění a jeho uplatnění v evropské vysokoškolské politice. AULA, 14, 4. Retrieved from: http://www.csvs.cz/aula/clanky/04-2006-4-paradigma.pdf.

Tawil, S., \& Cougoureux, M. (2013). Revisiting learning: The treasure within. Assessing the influence of the 1996 Delors Report. UNESCO Education Research and Foresight; Occasional paper, 4. Retrieved from: http://unesdoc.unesco.org/images/0022/002200/220050e.pdf

Toffler, A., \& Toffler, H. (1996). Utváranie novej civilizácie. Politika tretej vlny. Bratislava: Open Windows.

Thyssen, M. (2016). Keynote speech at the launch event of the "New Skills Agenda for Europe", Brussels. Retrieved from: https://ec.europa.eu/ commission/2014-2019/thyssen/announcements/keynote-speech-launchevent-new-skills-agenda-europe-brussels_en.

UNESCO. (2014). Teaching and learning: Achieving quality for all. education for all global monitoring report. Retrieved from: http://en.unesco.org/gemreport/report/2014/teaching-and-learning-achieving-quality-all\#sthash.hDU 9TNzX.dpbs

Veselý, A. (2005). Co je a není společnost vědění? AULA,13, 3. Retrieved from: www.csvs.cz/aula/clanky/02-2005-3-co-je.pdf. 